\title{
EARLY CEDAR RAPIDS SWEDISH CHURCHES
}

\author{
By B. L. WICK *
}

Cedar Rapids was a very different town in 1885 , with its 15,000 people, as compared with the population of today of 75,000 . I cannot go back to sixty years ago as a resident of this city, as the Rev. Carl Manfred has told you, but I do go back in continual residence here for fifty-one years. In searching the records in the courthouse I find that the Swedish Evangelical Saron church, now changed to the St. Mark's Lutheran church, was organized November 9, 1885, under the leadership of the Rev. C. E. Cesander, in accordance with the ordinances of the Swedish Evangelical Lutheran Augustana Synod of America. The organization was to be managed by a board of trustees composed of no less than three and no more than seven members. The trustees selected for the first year were C. E. Anderson, John Anderson and August Anderson.

Their services for a number of years were held in the old Dows block at the corner of Second avenue and Second street, where Mrs. Heleen, well known to most of us, served as an organist for a long time. The first services in this church were held in the month of December 1891. In order to defray the expenses, oyster suppers and other entertainments were frequently held, to which the young unmarried people contributed largely in maintaining the organization.

The leading members, all of whom were living on the west side of the river, then known as Kingston, were Carl and John Sundberg, John Holmquist, the Hendrickson family, Gus Goodman, Gus Johnson, Ernest Ahlgren, John and Gus Lundine, Kullander's, the Johnson's, Melbe's, Norholm's and many others. The women of the church should not be omitted, as perhaps they accom-

\footnotetext{
* An address by B. L. Wick at the Sixtieth anniversary since the founding of Saron Lutheran church in Cedar Rapids, delivered November 9,1945 . Mr. Wick died at Cedar Rapids October 8, 1947. 468
} 
plished more than the men providing for the pay of visiting ministers and entertainment for the young people.

I recall with gratitude having drawn a will for Mathilda Carlson, leaving a bequest for the payment of the balance on the church mortgage amounting to a thousand dollars, and I recall the gathering at the church parlors when this money was paid and the note and mortgage burned by the minister in the presence of a large gathering. I also remember distinctly drawing a will for Josephine Sundberg, leaving a bequest in the amount of a thousand dollars, such bequest to be used as directed for the interior decorations of this church.

Who does not recall the name of the Rev. C. T. Sandstrom, who lived here for a year or more until his death in March 1913, and who devoted so much of his time both in collecting funds and adding to the membership of the church. Few if any have shown as much interest and devoted so much of his time and energy to the upbuilding of the congregation as this aged and unknown personage, who came here as a stranger and who died beloved by all with whom he had come in contact.

These adopted citizens in this new country sought employment in shops and mills and in factories, with large families to provide for, but still they contributed from their small earnings to keep up the organization which they had helped to found.

\section{MEAGER IMPROVEMENTS ENJOYED}

On this side of the river sixty years ago, there were only a few wooden sidewalks which generally drifted down the river with the spring freshets and were pulled back by horsepower by the father of Charlie Loomis, who says he had to help with this disagreeable task. John M. Mitchell who came to live in this neighborhood in 1885 knew most of these Swedish settlers and worked side by side with them in the railway shops, recently told me that he paid three dollars a week for board, eggs were selling at ten cents a dozen, butter at eight cents 
a pound, steak at ten cents a pound and all the liver you wanted free. Such were the living conditions in this city sixty years ago.

Coming from a country ages old, these Swedish pioneers scarcely realized this was a growing town. They were informed that the first grist mill was erected in 1843, the first schoolhouse erected in 1847 and that Joseph Greene, the first postmaster, carried all the mail in his hat that came by stage once a week. There was no postoffice, and the department today is duly organized with one hundred and thirty paid employees. The Gazette began its appearance in 1884, with small prospects of existing very long, but it is now the leading newspaper in eastern Iowa with a circulation of more than 48,000 subscribers.

John Vardy opened his home for religious worship on the east side of the river in 1842 which was really the first feeble attempt for the conduct of a place of worship. This little cottage on account of its history, has been removed to Bever park as a reminder of the first beginnings of the religious work begun in this city.

The United Presbyterian church was organized in 1851, being the first organized church up to that time on the west side of the river.

We have in this city John S. Ely, 92 years of age, and C. G. Greene, nearly 90 years of age, both born here and both have seen this city grow from a mere frontier village with a few scattered wooden shacks and log cabins erected amid the brush piles and which now has grown to become a city built of brick, stone and cement with a memorial building seating four thousand people, and with a modern courthouse excelled by none in the state. All this has been accomplished by the enterprising citizens of this city during the lifetime of these two men.

\section{Brought Unique Customs}

Here Swedish immigrants brought their unique customs and their euphonius language all imbued with the faith of their fathers wherever they settled. 
A few weeks ago I heard a member of the English parliament tell us in this city, of the destruction of much property in England and of the bombing of many people, but that the English people still possessed a spirit, that they were not crushed, and he ended his talk by saying, "There will always be an England."

While I have traveled much in this country and visited many of the Swedish communities, I have heard it often said, "There will always be a place of worship; that faith is an anvil which has worn out many hammers."

The church services during the first years were conducted in Swedish, but as the younger members grew up and not being familiar with the language of their fathers, they insisted on a change and gradually the Swedish language was abandoned and English took its place.

In conversation recently with an old member of the church, she said, "The singing of the hymns in Swedish always reminds me of the little church in my old home in Vermland." That recalls the Scotch saying that whenever a Scotchman passes a store where they are dispensing tea, it always reminds him of "bonnie Scotland."

There has always been a strong feeling among the people of Sweden towards the emigrants who departed for other lands and they have kept up a friendly relationship between the old homes and the new homes founded across the sea.

I was only to speak of Cedar Rapids of sixty years ago and will return again to the conditions as they existed then. In discussing the matter with John S. Ely a short time ago he related that he could stand on top of the Roosevelt hotel and view the buildings which have been erected of brick and stone, of the many bridges crossing the river and of the paved streets, and that he could truthfully say, "I was here first." All these buildings and improvments have been made during the lifetime of people still living in our midst. I mentioned some of the changes that I had noticed and he smiled 
and replied that "everything has been changed since I was a boy." He said, "I used to ford the river in a wagon just north of First avenue and was told that it was safe in crossing if the big boulder in the middle of the river appeared above the water's edge, but not otherwise. The big boulder is still there. Everything else is changed."

\section{Before the Electrical Era}

You must remember that sixty years ago was "the horse and buggy days" in this country, but perhaps people were happier and more content then than they are today with all these modern comforts. You must remember that sixty years ago was before the electric lights came into general use, before the radio, the telephone and the automobile, as well as the chain stores. Sixty years ago there were stores scattered all ovel town, doing a small business it's true, but the owners made a living. Today the chain stores are sweeping the small stores out of existence.

This is true of Cedar Rapids, that during these last sixty years the city has kept up with the times, erected factories to such an extent that it is generally known as the manufacturing center of the middle west largely due to the farsighted and enterprising citizens.

I might add that these early adopted citizens who came here to make their homes, and their descendants, have in a large measure contributed much in the upbuilding of the city where a century ago a few frontiersmen founded the town without plans and without funds. During all these years adopted citizens observed the laws of the country and loyally supported the church of their fathers which has been the keynote of their unsullied characters. 
Copyright of Annals of Iowa is the property of State of Iowa, by \& through the State Historical Society of Iowa and its content may not be copied or emailed to multiple sites or posted to a listserv without the copyright holder's express written permission. However, users may print, download, or email articles for individual use. 